\title{
Local Scale Edaphic Surveys in and out of a Pericopsis elata (Harms) Meeuwen Natural Forest Stand in East Cameroon
}

\author{
Georges Kogge Kome*, Adalbert Adibime Onana, Mamouda Ngoucheme, Fritz Oben Tabi \\ Department of Soil Science, Faculty of Agronomy and Agricultural Sciences (FASA), University of Dschang, \\ Dschang, Cameroon \\ Email: *komegeo@yahoo.fr
}

How to cite this paper: Kome, G.K., Onana, A.A., Ngoucheme, M. and Tabi, F.O. (2018) Local Scale Edaphic Surveys in and out of a Pericopsis elata (Harms) Meeuwen Natural Forest Stand in East Cameroon. Open Journal of Soil Science, $\mathbf{8}$, $1-15$.

https://doi.org/10.4236/ojss.2018.81001

Received: November 18, 2017

Accepted: January 5, 2018

Published: January 8, 2018

Copyright $\odot 2018$ by authors and Scientific Research Publishing Inc. This work is licensed under the Creative Commons Attribution International License (CC BY 4.0).

http://creativecommons.org/licenses/by/4.0/

\begin{abstract}
One of the problems limiting high survival rates of Pericopsis elata (afrormosia, assamela), a high value timber species, is lack of data on its pedological requirements. A study was conducted in the East Region of Cameroon to identify possible soil properties favoring its spatial distribution. Two test areas, in and out of a Pericopsis elata natural forest stand were identified and in each sampling units of $50 \times 50 \mathrm{~m}$ delineated. Thirty eight and sixteen quadrats in and out of the stands were respectively sampled for soil physico-chemical properties, number of stems and diameter at breast height. Soil samples in each quadrat were analyzed following standard laboratory procedures. Soil properties were tested for normality and compared for the two sites using Student's t-test. Principal component analysis and correlation analysis were performed on tree and soil data to identify soil factors responsible for spatial distribution. From our findings, key soil indicators favouring Pericopsis elata distribution appear to be acidity (soil $\mathrm{pH}$ and exchangeable acidity), base status (base saturation and exchangeable bases) and texture (clay content). More specifically, optimal soil conditions for growth and survival of Pericopsis elata are: $\mathrm{pH}(4.1-5.0)$, exchangeable acidity $\left(<4.67 \mathrm{cmolc} \cdot \mathrm{kg}^{-1}\right)$, base saturation $(6.2 \%-17.8 \%)$, and clay content $(24.0 \%-49.0 \%)$, which should be considered in site selection for reforestation with Pericopsis elata.
\end{abstract}

\section{Keywords}

Assamela, Afrormosia, Soil Properties, Rainforest, Cameroon

\section{Introduction}

Soil is an important component of forest and woodland ecosystems as it helps 
regulate important ecosystem processes such as nutrient uptake, decomposition, and water availability [1]. It has been reported that the influence of soil properties on plant communities within tropical forests is controversial [2]. However, the intrinsic link between distribution patterns of forest tree species and edaphic properties has been reported in many studies [3] [4] [5] [6], implying that soil properties are responsible for maintaining growth and survival of particular tree species within tropical forests [7] [8] [9]. The growth and survival of forest tree species as conditioned by soil fertility status, among other factors, will in the long run determine the abundance and distribution patterns at the landscape scale [8], and even at the local scale [10]. Emphasizing on plant species distribution patterns along environmental factors such as soils is important for several reasons [5], especially for successful ecological restoration and the establishment of plantations, where better insight into the environmental requirements of the species is needed [7]. Such relations are also very important for integrated and sustainable flora management programmes [11]. The distribution and abundance of plant species in any environment can also serve as indications of the variation in biophysical components of the environment such as soil, water and topography among others [9]. Soil properties are generally controlled by a combination of biotic and abiotic factors that vary across the landscape, and it is this variability that influences soil nutrient pools [12], which in turn account for differential patterns in plant growth and distribution through the availability of soil nutrients [13]. Additionally, the soil system remains an indispensable part of biogeochemical cycles wherein the soil continually acts as a source of nutrients for tree growth in tropical forests [14].

Pericopsis elata (Harms) Meeuwen (Fabaceae), commonly known as Afrormosia or Assamela, is a high value tropical timber species endemic to the Congo Basin and parts of West Africa that suffers regeneration problems [15]. It is considered as "Endangered Alcd" by the International Union for Conservation of Nature (IUCN), and is listed on the Convention on International Trade in Endangered Species of Wild Fauna and Flora (CITES) [16]. Very few studies have been carried out with an attempt to explain the relationship that exists between edaphic properties and distribution patterns of $P$. elata within the Congo Basin. For example, earlier studies showed that $P$. elata was among species most representative on clay-rich soils in semi-deciduous forests of the Democratic Republic of Congo [2]. Field experiments aiming to assess the performance of nursery-raised seedlings of $P$. elata in logged forests in South-Eastern Cameroon revealed that the species tolerates a wide range of soil types but these were not specified [17] [18]. Rather, the studies revealed that the performance of $P$. elata seedlings was strongly influenced by light availability, an observation which is in line with that reported in the Democratic Republic of Congo by Unmunay et al. [19]. Again, the role of soil fertility was not considered by the latter. Furthermore, Bourland et al. [20] report that no data are available regarding the potential pedological requirements of $P$. elata. Thus, challenges in measuring edaphic conditions regulating $P$. elata survival and growth abound. Until now, there are 
no studies that have simultaneously examined the influence of soil physical and chemical properties on the distribution of $P$. elata alongside the establishment of edaphic requirements for its survival and development. Also, there is a debate on the origin of $P$. elata stems: anthropogenic disturbances [16] [21] versus edaphic properties. In this study, conducted at the local scale, we determine possible soil indicators suitable for survival of $P$. elata, through a survey in and out of a $P$. elata natural forest stand. The edaphic properties determined in this study will stimulate further research gearing towards the establishment of potential edaphic requirements of this valuable timber species.

\section{Materials and Methods}

\subsection{Description of Study Area and Sampling Sites}

The study was carried out in a gathered forest management unit (FMU, 10-030 and 10-031) of PALLISCO Company in the East Region of Cameroon. The gathered FMU has a total surface area of 118,052 ha (FMU 10-030 = 76,850 ha and FMU 10-031 = 41,202 ha), located between latitudes $3^{\circ} 05^{\prime} \mathrm{N}$ and $3^{\circ} 30^{\prime} \mathrm{N}$ and longitudes $14^{\circ} 00^{\prime} \mathrm{E}$ and $14^{\circ} 30^{\prime} \mathrm{E}$. The climate is the Equatorial Guinea sub-type with two seasons; the main wet season (September to November) and main dry season (December to February), and two minor seasons designated as short wet (March to May) and short dry (June to August). Mean annual temperature is $23.1^{\circ} \mathrm{C}$ and mean annual rainfall is $1566 \mathrm{~mm}$ [22]. Altitude varies between 600 and $760 \mathrm{~m}$ above sea level. The area mostly has semi-deciduous forests, with a vegetation canopy dominated by Meliaceae, Sterculiaceae and Ulmaceae families [17]. The soils are mainly ferralitic (Ferralsols) [23] and are developed from various parent materials such as micaschists, gneisses and granites [24]. A dense hydrographic network exists with many streams while areas of low altitudes $(<600 \mathrm{~m})$ contain marshes and raffia swamps (Figure 1). Two sites located in the northeastern part of the FMU, about $8 \mathrm{~km}$ away from Makalaya (a forest camp in the gathered FMU), were chosen for the study, given that these sites had undisturbed (natural) forest. The two sites, adjacent to one another and separated by a distance of about $1000 \mathrm{~m}$ were chosen based on the abundance of $P$. elata stems in each site (Authors, field observation). From field observations, the site of high $P$. elata stems had a distinct reddish yellow soil colour (5YR 6/8) compared to the site of low $P$. elata stems which had a dark reddish colour (10R $3 / 6)$.

\subsection{Field Methods, Data Collection and Soil Sampling}

Data collection and soil sampling were done in October 2014. In each site, a rectangular plot of 10 ha $(200 \times 500 \mathrm{~m})$ was demarcated and within each, square sub plots of $0.25 \mathrm{ha}(50 \times 50 \mathrm{~m})$ were established, following procedures outlined by Picard and Gourlet-Fleury [25]. In all, thirty eight sampling units of $50 \times 50$ $\mathrm{m}$ were established inside the $P$. elata stand while sixteen sampling units were delineated outside the $P$. elata stand. In each sub plot, diameter at breast height 


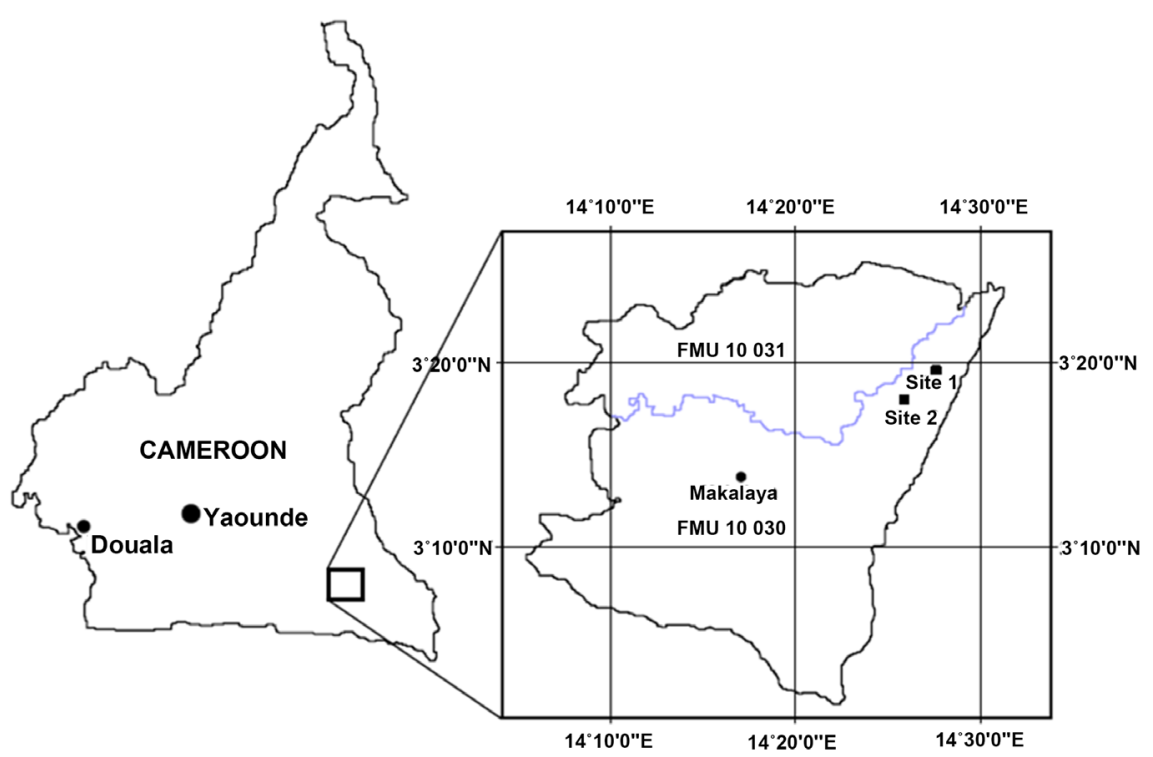

Figure 1. Location of the study area in the East Region of Cameroon showing the gathered FMUs (FMU 10-030 and FMU 10-031). The study sites are represented by the black squares in the north-eastern part of FMU 10-030. Site 1 is the area rich in P. elata stands while Site 2 is the area outside $P$. elata stands. The Boumba River (shown in blue) flows westbound across the study area and marks the boundary between the gathered FMUs.

(dbh) was measured and individual trees counted to obtain the number of stems per sub plot. Only trees with $\mathrm{dbh}>30 \mathrm{~cm}$ were considered because $\mathrm{dbh}>30 \mathrm{~cm}$ for the species constitute the minimum fertile and effective fruiting diameters [26], capable of reproducing. Within each sampling unit, soil samples were randomly collected at two depths: $0-20 \mathrm{~cm}$ and $20-40 \mathrm{~cm}$, and bulked to obtain composite samples for each of the depths. These depths were chosen based on the fact that nutrient cycling within tropical forests occurs primarily within the upper layer of the soil, following decomposition of plant litter [14]. Soil samples were collected and stored in polythene bags.

\subsection{Laboratory Analysis}

Fresh soil samples from the field were air-dried at room temperature, crushed and sieved through a $2 \mathrm{~mm}$ sieve. The $<2 \mathrm{~mm}$ soil fraction was analyzed for both physical and chemical properties. Particle size analysis was done following the hydrometer method [27]. Soil $\mathrm{pH}$ was determined electrometrically with a 1:2.5 soil: $\mathrm{H}_{2} \mathrm{O}$ and 1:2.5 soil: $\mathrm{KCl}$ ratio. Organic carbon (OC) was determined by the Walkley and Black wet combustion method as described by Pauwels et al. [28]. Exchangeable bases $\left(\mathrm{Ca}^{2+}, \mathrm{Mg}^{2+}, \mathrm{Na}^{+}, \mathrm{K}^{+}\right)$were determined following the Schollenberger method using a $1 \mathrm{M}$ ammonium acetate solution buffered at $\mathrm{pH}=7$. The concentrations of $\mathrm{Na}^{+}$and $\mathrm{K}^{+}$in the extract were determined by flame photometry while $\mathrm{Ca}^{2+}$ and $\mathrm{Mg}^{2+}$ were determined by complexometry using a 0.002 $\mathrm{M} \mathrm{Na}_{2}$-EDTA solution. Cation exchange capacity (CEC) was determined as a direct continuation of the Schollenberger's method using a $1 \mathrm{~N} \mathrm{KCl}$ saturation 
solution. Exchangeable acidity $\left(\mathrm{Al}^{3+}+\mathrm{H}^{+}\right)$was determined following procedures outlined by Dipak and Abhijit [29] using a $1 \mathrm{~N} \mathrm{KCl}$ solution for soil leaching. Effective CEC (ECEC) and base saturation (BS) were determined by the summation method [28].

\subsection{Statistical Analysis}

Descriptive statistics were performed for soil physical and chemical properties in and out of the $P$. elata forest stand. Mean values of soil properties between the two sites were compared using the Student's t-test. The Shapiro-Wilk test [30] was used to test for normality of soil properties within each site. Based on the distributions obtained in the $P$. elata stand, optimal soil conditions for $P$. elata distribution were established for surface and subsurface soil properties using normally distributed properties. Optimal soil conditions within 0.25 ha sub plots with $\geq 5$ stems, 3 - 4 stems, 1 - 2 stems and sparse (no stem) were respectively considered highly suitable (S1), moderately suitable (S2), marginally suitable (S3) and not suitable (N) classes following the FAO land suitability classification [31]. The aforementioned was refined with soil data available in the literature for the Congo Basin. Correlation analysis was carried out to identify soil properties correlated with tree stems per sub plot. Principal component analysis was performed on tree and soil data in the $P$. elata stand to identify factors responsible for the variation in tree population and soil properties. Statistical analyses were facilitated with SPSS software for windows (Version 19).

\section{Results}

Soil physical characteristics within $0-20 \mathrm{~cm}$ of soil depth showed that in both sites, the dominant soil fraction was clay. In the $P$. elata stand, clay content ranged between 24.0 and $49.0 \%$ (mean $=37.1 \%$ ), silt ranged between 8.0 and $34.0 \%($ mean $=16.8 \%)$, fine sand ranged between 3.0 and $37.0 \%($ mean $=20.7)$ and coarse sand ranged between 11.0 and $40.0 \%$ (mean $=25.4 \%$ ). Out of the $P$. elata stand, clay content ranged between 31.0 and 55.0\% (mean $=43.6 \%$ ), silt ranged between 10.0 and $26.0 \%$ (mean $=18.4 \%$ ), fine sand ranged between 18.0 and $31.0 \%$ (mean $=24.5 \%)$ and coarse sand ranged between 7.0 and $17.0 \%$ (mean $=13.5 \%)$. Soils in the $P$. elata stand had a sandy clay texture while those out of the stand had a clayey texture. There was a significant difference in the mean values of clay and sand contents in and out of soils under $P$. elata stands ( $\mathrm{p}$ $=0.001$ for clay; $\mathrm{p}=0.004$ for fine sand; $\mathrm{p}<0.001$ for coarse sand) (Table 1 ).

Soils in the $P$. elata stand were generally less acidic than those outside. For surface soils at $0-20 \mathrm{~cm}$ soil depth, there was no significant difference in soil $\mathrm{pH}$ between both sites. However, there existed a significant difference in mean values of sub-surface soil $\mathrm{pH}(20-40 \mathrm{~cm})(\mathrm{p}<0.001)$ (Table 2). Exchangeable acidity $\left(\mathrm{Al}^{3+}+\mathrm{H}^{+}\right)$was significantly higher out of $P$. elata stands $(\mathrm{p}<0.001)$. In both sites, OC decreased with soil depth, ranging from $3.2 \%$ to $0.7 \%$ in the $P$. elata stand and $2.9 \%$ to $0.9 \%$ out of the stand. 
Table 1. Comparison of mean $( \pm \mathrm{SE})$ soil physical properties $(0-20 \mathrm{~cm})$ in and out of $P$. elata stands.

\begin{tabular}{ccccc}
\hline \multirow{2}{*}{ Soil characteristics } & \multicolumn{2}{c}{ P. elata stand } & \multirow{2}{*}{ t-value } & Probability \\
\cline { 2 - 4 } & Inside $(\mathrm{n}=38)$ & Outside $(\mathrm{n}=16)$ & & \\
\hline Clay (\%) & $37.1 \pm 1.1$ & $43.6 \pm 1.4$ & -3.42 & $0.001^{\star}$ \\
Silt (\%) & $16.8 \pm 0.9$ & $18.4 \pm 1.0$ & -0.98 & 0.333 \\
Fine sand (\%) & $20.7 \pm 0.9$ & $24.5 \pm 0.8$ & -3.05 & $0.004^{\star}$ \\
Coarse sand (\%) & $25.4 \pm 1.1$ & $13.5 \pm 0.7$ & 9.4 & $<0.001^{*}$ \\
\hline
\end{tabular}

Notes: *: Mean values are significantly different at $\mathrm{p}<0.05$.

Table 2. Comparison of mean $( \pm \mathrm{SE})$ soil chemical properties between sites in and out of P. elata stands.

\begin{tabular}{|c|c|c|c|c|c|c|}
\hline \multirow{2}{*}{$\begin{array}{c}\text { Soil } \\
\text { characteristics }\end{array}$} & \multirow[t]{2}{*}{ Depth $(\mathrm{cm})$} & \multirow[t]{2}{*}{ Unit } & \multicolumn{2}{|c|}{ P. elata stands } & \multirow[t]{2}{*}{ t-value } & \multirow[t]{2}{*}{ Probability } \\
\hline & & & $\begin{array}{l}\text { Inside } \\
(\mathrm{n}=38)\end{array}$ & $\begin{array}{l}\text { Outside } \\
(\mathrm{n}=16)\end{array}$ & & \\
\hline $\mathrm{pH}-\mathrm{H}_{2} \mathrm{O}$ & $0-20$ & - & $4.18 \pm 0.03$ & $4.07 \pm 0.06$ & 1.99 & 0.06 \\
\hline $\mathrm{pH}-\mathrm{H}_{2} \mathrm{O}$ & $20-40$ & - & $4.79 \pm 0.02$ & $3.97 \pm 0.02$ & 23.03 & $<0.001^{\star}$ \\
\hline OC & $0-20$ & $\%$ & $2.1 \pm 0.1$ & $2.9 \pm 0.1$ & -5.38 & $<0.001^{\star}$ \\
\hline $\mathrm{OC}$ & $20-40$ & $\%$ & $1.3 \pm 0.1$ & $2.0 \pm 0.1$ & -5.49 & $<0.001^{\star}$ \\
\hline $\mathrm{Ca}^{2+}$ & $0-20$ & $\mathrm{cmolc} \cdot \mathrm{kg}^{-1}$ & $0.51 \pm 0.02$ & $0.58 \pm 0.03$ & -1.77 & 0.083 \\
\hline $\mathrm{Mg}^{2+}$ & $0-20$ & $\mathrm{cmolc} \cdot \mathrm{kg}^{-1}$ & $0.16 \pm 0.01$ & $0.26 \pm 0.04$ & -2.44 & $0.025^{\star}$ \\
\hline $\mathrm{K}^{+}$ & $0-20$ & $\mathrm{cmolc} \cdot \mathrm{kg}^{-1}$ & 0.005 & 0.01 & $\mathrm{Nd}$ & $\mathrm{Nd}$ \\
\hline $\mathrm{Na}^{+}$ & $0-20$ & $\mathrm{cmolc} \cdot \mathrm{kg}^{-1}$ & 0.004 & 0.01 & $\mathrm{Nd}$ & $\mathrm{Nd}$ \\
\hline$\left(\mathrm{Al}^{3+}+\mathrm{H}^{+}\right)$ & $0-20$ & $\mathrm{cmolc} \cdot \mathrm{kg}^{-1}$ & $4.02 \pm 0.06$ & $5.76 \pm 0.07$ & -17.45 & $<0.001^{\star}$ \\
\hline CEC & $0-20$ & cmolc $\cdot \mathrm{kg}^{-1}$ & $6.46 \pm 0.14$ & $7.79 \pm 0.12$ & 7.26 & $<0.001^{\star}$ \\
\hline ECEC & $0-20$ & $\mathrm{cmolc} \cdot \mathrm{kg}^{-1}$ & $4.7 \pm 0.07$ & $6.62 \pm 0.09$ & -16.29 & $<0.001^{\star}$ \\
\hline BS & $0-20$ & $\%$ & $10.6 \pm 0.5$ & $11.0 \pm 2.7$ & -0.50 & 0.62 \\
\hline
\end{tabular}

Notes: ${ }^{*}$ : Mean values are significantly different at $\mathrm{p}<0.05$; SE: Standard error of means; Nd: Not determined.

In both sites, exchangeable bases were generally low in concentration. $\mathrm{Na}^{+}$and $\mathrm{K}^{+}$had the lowest concentrations, a trend similar to those observed in the humid forest soils of south southern Nigeria [9], in ferralitic forest soils of the Democratic Republic of Congo [2] and in most soils of lowland humid tropical forests [32] [33]. Between both sites, there was a significant difference in mean values of organic carbon $(\mathrm{p}<0.001), \mathrm{Mg}^{2+}(\mathrm{p}<0.025)$ and CEC $(\mathrm{p}<0.001)$. There was a significant negative correlation between $P$. elata stems per sub plot and soil $\mathrm{pH}$, $\mathrm{OC}$ and $\mathrm{Ca}^{2+}$ within $20 \mathrm{~cm}$ soil depth, and a positive correlation between tree stems and clay content (Table 3 ).

With respect to variation in soil properties and number of stems per sub plot, principal component analysis yielded 4 components (PC) and these were 
Table 3. Correlation between $P$. elata stems and soil characteristics.

\begin{tabular}{|c|c|c|c|c|c|c|c|c|c|c|c|c|c|c|c|}
\hline & $\mathrm{pH}-\mathrm{H}_{2} \mathrm{O}$ & $\mathrm{pH}-\mathrm{KCl}$ & $\mathrm{pH}-\mathrm{H}_{2} \mathrm{O} \#$ & pH-KCl\# & OC & OC\# & $\mathrm{Ca}^{2+}$ & $\mathrm{K}^{+}$ & $\mathrm{Mg}^{2+}$ & CEC & ECEC & BS & Clay & Silt & Sand \\
\hline P. elata stems & -0.17 & $-0.37^{\star}$ & -0.12 & -0.14 & $-0.33^{\star}$ & -0.18 & $-0.35^{\star}$ & -0.1 & -0.16 & -0.07 & 0.01 & -0.31 & $0.36^{*}$ & -0.22 & -0.02 \\
\hline
\end{tabular}

Notes: *: Correlation is significant at $\mathrm{p}<0.05$; \#: $20-40 \mathrm{~cm}$ soil depth.

retained for interpretation of the variation in soil properties and number of stems. A total of $76 \%$ of the variation observed is explained by these 4 components (Table 4).

PC1 had high positive loadings on exchangeable acidity (0.97) and ECEC (0.93), and high negative loadings on sub-surface soil $\mathrm{pH}(-0.95)$ and coarse sand (-0.79). PC1 also had moderate positive loadings on surface soil CEC (0.67) and subsurface OC (0.61). The loading on number of stems was small and negative $(-0.3)$. PC1 explained up to $45 \%$ in the variation and was named soil acidity/saturation factor. Considering the grouping of number of stems mentioned earlier, units with $\geq 5$ stems/sub plot will have an exchangeable acidity range of $3.3-4.7 \mathrm{cmolc} \cdot \mathrm{kg}^{-1}$ (mean $=4.0 \mathrm{cmolc} \cdot \mathrm{kg}^{-1}$ ) and $\mathrm{pH}$ range of $4.6-5.0$ (mean $=4.8)$. Sites out of the $P$. elata stand will have exchangeable acidity ranging between $5.3-6.3 \mathrm{cmolc} \cdot \mathrm{kg}^{-1}\left(\right.$ mean $\left.=5.76 \mathrm{cmolc} \cdot \mathrm{kg}^{-1}\right)$ and a $\mathrm{pH}$ range of $3.8-4.2$ $($ mean $=3.97$ ). These $\mathrm{pH}$ ranges fall within the range of acidic soils reported by Amani et al. [2] in acidic forest soils of the Democratic Republic of Congo where high $P$. elata stands were observed. PC2 was named as base status factor because it had high positive loadings on base saturation (0.96), $\mathrm{Ca}^{2+}(0.8)$ and $\mathrm{Mg}^{2+}$ (0.76). Threshold values for these three variables in the $P$. elata stand range from $0.04-0.31 \mathrm{cmolc} \cdot \mathrm{kg}^{-1} \mathrm{Mg}^{2+}\left(\right.$ mean $\left.=0.16 \mathrm{cmolc} \cdot \mathrm{kg}^{-1}\right), 6.2 \%-17.8 \% \mathrm{BS}($ mean $=$ $10.6 \%)$ and $0.32-0.88 \mathrm{cmolc} \cdot \mathrm{kg}^{-1} \mathrm{Ca}^{2+}\left(\right.$ mean $\left.=0.51 \mathrm{cmolc} \cdot \mathrm{kg}^{-1}\right)$. Out of the $P$. elata stand, values for these variables range from $0.04-0.56 \mathrm{cmolc} \mathrm{kg}^{-1} \mathrm{Mg}^{2+}$ $\left(\right.$ mean $\left.=0.26 \mathrm{cmolc} \cdot \mathrm{kg}^{-1}\right), 7.6 \%-15.9 \%$ BS $($ mean $=11 \%)$ and $0.4-0.8$ cmolc $\cdot \mathrm{kg}^{-1} \mathrm{Ca}^{2+}$ (mean $\left.=0.58 \mathrm{cmolc} \cdot \mathrm{kg}^{-1}\right)$. PC3 had a high positive loading on surface soil $\mathrm{pH}(0.82)$ and a moderate negative loading on number of stems per sub plot $(-0.6)$ and was named topsoil-pH/tree factor. This component indicates that a high number of stems per sub plot is antagonistic to surface soil $\mathrm{pH}(0-20$ $\mathrm{cm})$, contrary to that of sub-surface $\mathrm{pH}(20-40 \mathrm{~cm})$. Following the arguments raised in the first component, it is suggested that $P$. elata distribution is greatly influenced by subsurface soil $\mathrm{pH}$. Soil $\mathrm{pH}$ provides a good indication of the chemical status of the soil and can be used in part to determine potential plant growth in forest milieu, given that soil $\mathrm{pH}$ greatly influences plant nutrient availability [33]. PC4, known as the texture factor indicated that high silt contents do not favour $P$. elata. The edaphic properties have been reported in four suitability classes (Table 5 ).

\section{Discussion}

\subsection{Influence of Edaphic Properties on Distribution of $P$. elata}

The correlation between $P$. elata stems and clay content gives evidence that the distribution of $P$. elata is a function of soil texture. Clay is generally considered 
Table 4. Rotated component matrix ${ }^{\mathrm{a}}$ of principal components.

\begin{tabular}{|c|c|c|c|c|}
\hline \multirow{2}{*}{ Soil properties } & \multicolumn{4}{|c|}{ Component } \\
\hline & 1 & 2 & 3 & 4 \\
\hline$\left(\mathrm{Al}^{3+}+\mathrm{H}^{+}\right)$ & 0.971 & & & \\
\hline $\mathrm{pH}-\mathrm{H}_{2} \mathrm{O}(20-40 \mathrm{~cm})$ & -0.950 & & & \\
\hline $\operatorname{ECEC}(0-20 \mathrm{~cm})$ & 0.932 & & & \\
\hline $\mathrm{pH}-\mathrm{KCl}(20-40 \mathrm{~cm})$ & -0.884 & & & \\
\hline Coarse sand $(0-20 \mathrm{~cm})$ & -0.793 & & & \\
\hline $\operatorname{CEC}(0-20 \mathrm{~cm})$ & 0.674 & & 0.334 & \\
\hline $\mathrm{OC}(20-40 \mathrm{~cm})$ & 0.610 & & 0.336 & 0.306 \\
\hline$O C(0-20 \mathrm{~cm})$ & 0.575 & & 0.397 & \\
\hline BS $(0-20 \mathrm{~cm})$ & & 0.962 & & \\
\hline $\mathrm{Ca}^{2+}(0-20 \mathrm{~cm})$ & & 0.806 & 0.344 & \\
\hline $\mathrm{Mg}^{2+}(0-20 \mathrm{~cm})$ & 0.410 & 0.766 & & \\
\hline $\mathrm{pH}-\mathrm{KCl}(0-20 \mathrm{~cm})$ & & & 0.829 & \\
\hline P. elata stems & 0.307 & & -0.608 & -0.386 \\
\hline Silt $(0-20 \mathrm{~cm})$ & & & & 0.902 \\
\hline
\end{tabular}

Notes: a: Extraction method, principal component analysis; Rotation method: Varimax with Kaiser normalization. Component 1 is the soil acidity/saturation factor; Component 2 is base status factor; Component 3 is the topsoil-pH/tree factor; Component 4 is the texture factor.

Table 5. Edaphic properties in and out of $P$. elata natural forest stand.

\begin{tabular}{ccccc}
\hline Soil properties & \multicolumn{4}{c}{ Suitability classes } \\
\hline pH-H $2 \mathrm{O}(0-20 \mathrm{~cm})$ & $4.10-4.30$ & $4.00-4.40$ & $4.00-4.60$ & $<4.00$ and $>5.00$ \\
$\mathrm{pH}-\mathrm{H}_{2} \mathrm{O}(20-40 \mathrm{~cm})$ & $4.60-4.90$ & $4.70-4.90$ & $4.60-5.00$ & $<4.0$ and $>5.00$ \\
OC $(0-20 \mathrm{~cm})(\%)$ & $1.51-1.90$ & $1.23-2.97$ & $1.01-3.19$ & $<1.00$ \\
OC $(20-40 \mathrm{~cm})(\%)$ & $0.73-1.34$ & $1.08-1.85$ & $0.73-1.96$ & $<0.73$ \\
$\mathrm{Ca}^{2+}(0-20 \mathrm{~cm})\left(\mathrm{cmolc} \cdot \mathrm{kg}^{-1}\right)$ & $0.32-0.41$ & $0.34-0.64$ & $0.33-0.88$ & $<0.33$ and $>0.88$ \\
$\mathrm{Mg}^{2+}(0-20 \mathrm{~cm})\left(\mathrm{cmolc} \cdot \mathrm{kg}^{-1}\right)$ & $0.08-0.25$ & $0.05-0.18$ & $0.04-0.31$ & $<0.04$ and $>0.31$ \\
$(\mathrm{Al}+\mathrm{H})(0-20 \mathrm{~cm})\left(\mathrm{cmolc} \cdot \mathrm{kg}^{-1}\right)$ & $3.78-4.43$ & $3.71-4.31$ & $3.33-4.67$ & $>4.67$ \\
$\mathrm{CEC}(0-20 \mathrm{~cm})\left(\mathrm{cmolc} \cdot \mathrm{kg}^{-1}\right)$ & $4.99-6.59$ & $4.98-8.64$ & $4.85-8.00$ & $<4.85$ and $>8.64$ \\
$\mathrm{ECEC}(0-20 \mathrm{~cm})\left(\mathrm{cmolc} \cdot \mathrm{kg}^{-1}\right)$ & $4.26-4.92$ & $4.35-4.88$ & $3.85-5.46$ & $<3.85$ and $>5.50$ \\
$\mathrm{BS}(0-20 \mathrm{~cm})(\%)$ & $6.9-9.6$ & $6.6-11.5$ & $6.2-17.9$ & $<6.2$ and $>17.9$ \\
Clay $(0-20 \mathrm{~cm})(\%)$ & $34.6-45.6$ & $32.6-46.6$ & $24.6-48.6$ & $<24.0$ and $>50.5$ \\
Silt $(0-20 \mathrm{~cm})(\%)$ & $9.0-20.0$ & $10.0-26.0$ & $8.0-34.0$ & $<9.0$ and $>37.0$ \\
Fine sand $(0-20 \mathrm{~cm})(\%)$ & $14.7-26.3$ & $9.7-29.1$ & $3.2-36.9$ & $<10.0$ and $>37.0$ \\
Coarse sand $(0-20 \mathrm{~cm})(\%)$ & $20.1-29.1$ & $12.5-33.5$ & $10.9-39.7$ & $<11.00$ and $>40.00$ \\
\hline
\end{tabular}

Notes: S1: Highly suitable ( $\geq 5$ stems/0.25 ha); S2: Moderately suitable ( 3 - 4 stems/0.25 ha); S3: Marginally suitable (1 - 2 stems/0.25 ha); N: Not suitable (no stems). Source: Modified from Boyemba [34]. 
as the active part of soil because it plays a role in the supply and availability of nutrient elements [35]. The impact of edaphic heterogeneity on species assembly has been reported in rainforests of the Congo Basin, where differences in soil texture (clayey versus sandy soils) considerably influence biodiversity and habitat preference [2] [36] [37]. According to Silver et al. [38], soil texture is primarily responsible for nutrient availability in lowland tropical forests. Also, the observed effect of silt in this study is in line with observations made by Iwara et al. [9], where silt content was observed to have a strong influence on the distribution of some particular tropical lowland forest species such as Anthonota macrophylla. Although the soils in our study area are dominated by low activity clays such as kaolinite and $\mathrm{Fe}$ and $\mathrm{Al}$ oxides [24], it is suggested that clay content in this case plays an important role in the availability of acidic elements such as $\mathrm{Al}^{3+}$ in the soil solution. This observation is in accordance with the relationship between $P$. elata stems and soil $\mathrm{pH}$, indicating that a high number of $P$. elata stems may not be favoured at particular $\mathrm{pH}$ values ( $\mathrm{pH}$ between 4.0 and 5.0). It has been observed that $\mathrm{Al}^{3+}$ in acidic soils has a distinct negative effect on survival of some forest tree species [39] through Al toxicity. Increasing aluminum levels in the soil solution have been reported to decrease uptake and translocation of calcium, magnesium, and potassium [40]. The primary target of Al toxicity is the root apex and aluminium affects a host of different cellular functions. Exposure to $\mathrm{Al}$ causes stunting of the primary root and inhibition of lateral root formation in some plants. This phenomenon is still to be verified for $P$. elata. The resulting restricted root system is impaired in nutrient and water uptake, making the plant more susceptible to drought stress [40] [41]. However, Boyemba [34] observed that high concentrations of $\mathrm{Al}^{3+}$ inhibited proper growth and survival of $P$. elata in a humid tropical forest in the Democratic Republic of Congo. With respect to availability and uptake of Nitrogen, it has been reported that $P$. elata, being a Fabaceae, is a nitrogen-fixing plant thanks to its symbiotic relationship with some bacteria [42]. The supply of Nitrogen has been reported to exert strong control over the composition, diversity and productivity of many ecosystems [43]. This is because nitrogen metabolism is one of the most important factors often limiting plant growth in natural ecosystems [44]. Nitrogen-fixing trees such as $P$. elata have tree sources of inorganic N (nitrate, ammonium and atmospheric nitrogen) fixed by symbiotic bacteria, even though we did not determine nitrogen in this study. However, Nitrogen supply can be greatly reduced at high aluminium concentrations through the inhibition of specific enzymes responsible for nitrogen assimilation [45]. Soil $\mathrm{pH}$ also has an indirect influence on organic matter decomposition and nutrient availability by affecting soil microorganisms [32]. The relationship observed between $P$. elata stems and exchangeable $\mathrm{Ca}^{2+}$ is striking. Although calcium is one of the most abundant mineral elements in soil, this is not the case in tropical soils. Calcium has several distinct functions in higher plants [46], but $\mathrm{Ca}^{2+}$ concentration in this case seems to affect $P$. elata stems negatively. It has been observed that tree communities are greatly influenced by exchangeable bases $\left(\mathrm{Ca}^{2+}\right.$ and $\left.\mathrm{Mg}^{2+}\right)$ [9], 
[39]. Also, Iwara et al. [9] observed that low base saturation is suitable for establishment of particular tree species in humid tropical forests. The negative correlation between $P$. elata stems and soil $\mathrm{pH}$ suggests that high $\mathrm{pH}$ conditions $(\mathrm{pH}>5.0)$ reduce tree population, and so, $P$. elata is suggested to have a well defined acidity range necessary for its survival. John et al. [4] identified soil $\mathrm{pH}$ as the strongest factor that influenced the distribution of tree species in three tropical forests.

Organic matter plays an important role in binding soil cations and in ameliorating soil structure, thus providing a favorable condition for plant growth. Correlation analysis indicates that a high number of $P$. elata stems is favoured by low amounts of organic matter. This correlation could be explained by the classical relationship between clay and organic matter [47], given that there was a positive correlation between $P$. elata stems and clay content. The low organic matter content is certainly due to high rates of organic matter decomposition as influenced by the quality of litter type, which favours nutrient cycling [14] with the consequence of making nutrients available for immediate uptake by plants. Additionally, soil organic matter contains a large number of exchange sites (high surface area and hence high cation exchange capacity) that increase the capacity of the soil to adsorb these nutrients and prevent them from leaching below the rooting zone [48]. It has been reported that present $P$. elata patches in the study area considered in southeastern Cameroon are related to anthropogenic disturbances (most likely resulting from shifting cultivation that occurred ca. two centuries ago) [16]. However, other studies reveal that not all patches of African light-demanding tall trees (such as $P$. elata) are caused by human-induced disturbances [49]. In our study sites, no signs of anthropogenic disturbances (e.g. presence of charcoal or pottery sherds) were observed in the soil layers, contrary to the observations made by Bourland et al. [16] about $30 \mathrm{Km}$ away from our study site, where they found a link between anthropogenic disturbances and $P$. elata population. Among other factors, edaphic properties have been reported to significantly affect the distribution of many tree species within humid rainforests and semi-deciduous forests of the Congo Basin [2] [37] [42]. In a study of within-plot relationships between tree species occurrences and hydrological soil constraints in a lowland rainforest of French Guiana, it was reported that soil hydrological conditions (particularly soil drainage), were the main structuring factors of the local multispecies spatial pattern observed [50]. However, our study did not take into account groundwater availability (which could probably influence the spatial distribution of $P$. elata) due to the complexity in quantifying groundwater availability and also because the species has been reported to tolerate a wide range of water regimes ranging from well drained soils to seasonally waterlogged ones [7].

\subsection{Local Scale Edaphic Requirements for Survival of $P$, elata}

In the literature, the controversy that exists with respect to the influence of soil properties on the distribution of forest tree species has been argued either 
through experimentation or field exploration. For the case of $P$. elata, the survival rate within forest environments has been attributed to factors such as light availability [15] [17], influence of pests [20], herbivory [51] and edaphic heterogeneity [2] [34] [42]. The findings in the present study derive from field observation, wherein the distribution of $P$. elata is certainly influenced by soil properties among others. Therefore, the edaphic properties identified in this study could serve as a starting point for studies seeking to establish edaphic requirements for the survival of $P$. elata. The values of $\mathrm{pH}, \mathrm{CEC}, \mathrm{BS}$ and exchangeable bases observed in this study permit us to suggest that slightly acidic soils within a $\mathrm{pH}$ range from $4.10-4.30$ in surface soils $(0-20 \mathrm{~cm})$ and $4.60-4.90$ for sub-surface soils $(20-40 \mathrm{~cm})$, could be considered as baseline information that can guide or stimulate further research aiming at establishing pedological requirements of $P$. elata. In this study, our values for exchangeable acidity do not exceed $4.67 \mathrm{cmolc} \cdot \mathrm{kg}^{-1}$ within $40 \mathrm{~cm}$ soil depth, and so, further studies are highly recommended in order to complement these findings in other $P$. elata natural forest stands within the Congo Basin.

\section{Conclusion}

The results obtained show that site selection of $P$. elata is a function of varying nutrient concentrations at particular ranges of tolerance and are strongly influenced by soil acidity and texture. This study also shows that there is a link between soil properties and distribution of $P$. elata. Additionally, the results suggest that the main soil characteristics to be considered in plantation establishment are soil $\mathrm{pH}$, base status (CEC, base saturation and exchangeable bases), exchangeable acidity, OC and clay content. Since forest environments are very complex, coupled to the complex nature of the soil system, $P$. elata may grow on soils outside the ranges proposed in this study. Notwithstanding, values of soil properties reported indicate where $P$. elata may have the best chances of survival. The edaphic characteristics proposed serve as baseline information for the stimulation of future research within other sites endemic to this valuable species so as to complement the results reported in this study. Based on the results obtained, the following are suggested: the setup of experiments to monitor and evaluate the effects of different concentrations of acidic elements such as $\mathrm{Al}$ and Fe on $P$. elata seedling performance in nurseries.

\section{Acknowledgements}

This research was funded by the International Tropical Timber Organization (ITTO/CITES) through the National Agency for Support to Forestry Development (ANAFOR), project $\mathrm{N}^{\circ}$ : 0737/CS/ANAFOR/DG/DT/CA Assamela-FP. We are indebted to Mr. Paul Lagoute and Mr. Tekam Patrice of PALLISCO SARL Company for their invaluable assistance during field work.

\section{References}

[1] Forestry Commission (2011) Forests and Soil. UK Forestry Standard Guidelines. 
Forestry Commission, Edinburgh.

[2] Amani, A.C., Vleminckx, J., de la Thibauderie, T.D., Lejoly, J., Meerts, P. and Hardy, O.J. (2013) Species Responses to Edaphic Heterogeneity in Semi-Deciduous Forests from the Congo Basin. Greener Journal of Biological Sciences, 3, 365-374. https://doi.org/10.15580/GJBS.2013.10.112913997

[3] Lescure, J.P. and Boulet, R. (1985) Relationships between Soil and Vegetation in a Tropical Rain Forest in French Guiana. Biotropica, 17, 155-164. https://doi.org/10.2307/2388508

[4] John, R., Dalling, J.W., Harms, K.E., Yavitt, J.B., Stallard, R.F., Mirabello, M., Hubbell, S.P., Valencia, R., Navarrete, H., Vallejo, M. and Foster, R.B. (2007) Soil Nutrients Influence Spatial Distributions of Tropical Tree Species. Ecology, 104, 864-869.

[5] Toledo, M., Pena, C.M., Bongers, F., Alarcon, A., Balcazar, J., Chuvina, J., Leano, C., Licona, J.C. and Poorter, L. (2012) Distribution Patterns of Tropical Woody Species in Response to Climatic and Edaphic Gradients. Journal of Ecology, 100, 253-263. https://doi.org/10.1111/j.1365-2745.2011.01890.x

[6] Khairil, M., Wan, W.A.J. and Nizam, M.S. (2014) Edaphic Influences on Tree Species Composition and Community Structure in a Tropical Watershed Forest in Peninsular Malaysia. Journal of Tropical Forest Science, 26, 284-294.

http://www.jstor.org/stable/23723914

[7] Swaine, M.D. (1996) Rainfall and Soil Fertility as Factors Limiting Forest Species Distributions in Ghana. Journal of Ecology, 84, 419-428.

https://doi.org/10.2307/2261203

[8] Clark, D.B., Palmer, M.W. and Clark, D.A. (1999) Edaphic Factors and the Landscape Scale Distributions of Tropical Rain Forest Trees. Ecology, 80, 2662-2675. https://doi.org/10.1890/0012-9658(1999)080[2662:EFATLS]2.0.CO;2

[9] Iwara, A.I., Gani, B.S., Njar, G.N. and Deekor, T.N. (2011) Influence of Soil Physico-Chemical Properties on the Distribution of Woody Tree/Shrub Species in South-Southern Nigeria. Journal of Agricultural Sciences, 2, 69-75. https://doi.org/10.1080/09766898.2011.11884669

[10] Hall, J.S., McKenna, J.J., Ashton, P.M. and Gregoire, T.G. (2004) Habitat Characterizations Underestimate the Role of Edaphic Factors Controlling the Distribution of Entandrophragma. Ecology, 85, 2171-2183. https://doi.org/10.1890/03-0043

[11] Udoh, B.T., Ogunkunle, A.O. and Ndaeyo, N.U. (2007) Influence of Soil Series and Physico-Chemical Properties on Weed Flora Distribution at Moor Plantation Ibadan, Southwestern Nigeria. Journal of Agriculture and Social Sciences, 3, 55-58.

[12] Jenny, H. (1980) The Soil Resource: Origin and Behavior. 4th Edition, Springer-Verlag, New York. https://doi.org/10.1007/978-1-4612-6112-4

[13] Huston, M.A. (1980) Soil Nutrients and Tree Species Richness in Costa Rican Forests. Journal of Biogeography, 7, 147-157. https://doi.org/10.2307/2844707

[14] Vitousek, P.M. and Sanford, J.R.L. (1986) Nutrient Cycling in Moist Tropical Forest. Annual Review of Ecology and Systematics, 17, 137-167. https://doi.org/10.1146/annurev.es.17.110186.001033

[15] Ampofo, S.T. (1972) The Problem of Natural Regeneration of Pericopsis elata (Harms) van Meeuwen in Africa. Ghana Journal of Agricultural Sciences, 5, 241-245.

[16] Bourland, N., Cerisier, F., Daïnou, K., Smith, A.L., Hubau, W., Hans, B., Brostaux, Y., Fayolle, A., Biwolé, A.B., Fétéké, F., Gillet, J.F., Morin-Rivat, J., Lejeune, P., Tiba, 
E.N., van Acker, J. and Doucet, J.L. (2015) How Tightly Linked Are Pericopsis elata (Fabaceae) Patches to Anthropogenic Disturbances in Southeastern Cameroon? Forests, 6, 293-310. https://doi.org/10.3390/f6020293

[17] Ouédraogo, D.Y., Fayolle, A., Daïnou, K., Demaret, C., Bourland, N., Lagoute, P. and Doucet, J.L. (2014) Enrichment of Logging Gaps with a High Conservation Value Species (Pericopsis elata) in a Central African Moist Forest. Forests, 5, 3031-3047. https://doi.org/10.3390/f5123031

[18] Fayolle, A., Ouédraogo, D.Y., Ligot, G., Daïnou, K., Bourland, N., Tekam, P. and Doucet, J.L. (2015) Differential Performance between Two Timber Species in Forest Logging Gaps and in Plantations in Central Africa. Forests, 6, 380-394. https://doi.org/10.3390/f6020380

[19] Unmunay, P.M., Covey, K.R., Makana, J.-R. and Gregoire, T.G. (2017) Effect of Light, Fire and Weed Control on Establishment of Pericopsis elata Harms Regeneration. New Forests, 48, 735-752. https://doi.org/10.1007/s11056-017-9594-4

[20] Bourland, N., Kouadio, Y.L., Fétéké, F., Lejeune, P. and Doucet, J.-L. (2012) Ecology and Management of Pericopsis elata Harms Populations: A Review. Biotechnology, Agronomy, Society and Environment, 16, 486-498.

http://hdl.handle.net/2268/135821

[21] Tshibamba, J. (2016) Pedoanthrocological Approach for Studying the Origin of Percopsis elata (Harms) Van Meeuwen Populations in the Yoko Forest Reserve in the Democratic Republic of Congo (DRC). PhD Thesis, University of Kisangani, DRC.

[22] Hijmans, R.J., Cameron, S.E., Parra, J.L., Jones, P.G. and Jarvis, A. (2005) Very High Resolution Interpolated Climate Surfaces for Global Land Areas. International Journal of Climatology, 25, 1965-1978. https://doi.org/10.1002/joc.1276

[23] Kome, G.K., Tabi, F.O. and Enang, R.K. (2016) Statistical Relationships and Variability of Selected Properties of Xanthic and Rhodic Ferralsols in a Humid Tropical Forest of Cameroon. International Journal of Agriculture and Forestry, 6, 187-195.

[24] Yerima, B.P.K. and Van Ranst, E. (2005) Major Soil Classification Systems Used in the Tropics: Soils of Cameroon. Trafford Publishing, Victoria.

[25] Picard, N. and Gourlet-Fleury, S. (2008) Reference Manual for the Establishment of Permanent Plots within Production Forests in the Congo Basin. CIRAD, Montpellier.

[26] Bourland, N., Kouadio, Y.L., Colinet, G. and Doucet, J.L. (2010) Pericopsis elata (Hams) Meeuwen in the Southeastern Part of Cameroon: Ecological and Pedological Approaches to Improve the Management of an Endangered Commercial Timber Species. International Forestry Review, 12, 111.

http://hdl.handle.net/2268/78146

[27] Bouyoucos, G.J. (1962) Hydrometer Method Improved for Making Particle Size Analysis of Soil. Agronomy Journal, 54, 464-465. https://doi.org/10.2134/agronj1962.00021962005400050028x

[28] Pauwels, J.M., Van Ranst, E., Verloo, M. and Mvondo Ze, A. (1992) Soil Science Laboratory Manual. Methods of Soil and Plant Analysis, Equipment, Management of Glassware and Chemicals. Publications Agricoles No. 28, AGCD, Bruxelles.

[29] Dipak, S. and Abhijit, H. (2005) Physical and Chemical Methods in Soil Analysis. New Age International Limited Publishers.

[30] Shapiro, S.S. and Wilk, M.B. (1965) An Analysis of Variance Test for Normality. Biometrika, 52, 691-710. http://www.jstor.org/stable/2333709 
https://doi.org/10.2307/2333709

[31] FAO (1984) Land Evaluation for Forestry. FAO Forestry Paper 48, Rome.

[32] Silver, W.L., Scatena, F.N., Johnson, A.H., Siccama, T.G. and Sanchez, M.J. (1994) Nutrient Availability in a Montane Wet Tropical Forest: Spatial Patterns and Methodological Considerations. Plant and Soil, 164, 129-145. https://doi.org/10.1007/BF00010118

[33] Sollins, P. (1998) Factors Influencing Species Composition in Tropical Lowland Forest: Does Soil Matter? Ecology, 79, 23-30. https://doi.org/10.1890/0012-9658(1998)079[0023:FISCIT]2.0.CO;2

[34] Boyemba, F.B. (2011) Ecology of Pericopsis elata (Harms) Van Meeuwen (Fabaceae), Tropical African Tree with Aggregated Distribution. PhD Thesis, Université Libre de Bruxelles, Belgium.

[35] Jones, J.B. (2012) Plant Nutrition and Soil Fertility Manual. 2nd Edition, CRC Press, Taylor and Francis Group, Boca Raton. https://doi.org/10.1201/b11577

[36] Réjou-Méchain, M., Pélissier, R., Gourlet-Fleury, S., Couteron, P., Nasi, R. and Thompson, J.D. (2008) Regional Variation in Tropical Forest Tree Species Composition in the Central African Republic: An Assessment Based on Inventories by Forest Companies. Journal of Tropical Ecology, 24, 663-674. https://doi.org/10.1017/S0266467408005506

[37] Vleminckx, J., Drouet, T., Amani, C., Lisingo, J., Lejoly, J. and Hardy, O.J. (2015) Impact of Fine Scale Edaphic Heterogeneity on Tree Species Assembly in a Central African Rainforest. Journal of Vegetation Science, 26, 134-144.

https://doi.org/10.1111/jvs.12209

[38] Silver, W.L., Neff, J., McGroddy, M., Veldkamp, E., Keller, M. and Cosme, R. (2000) Effects of Soil Texture on Belowground Carbon and Nutrient Storage in a Lowland Amazonian Forest Ecosystem. Ecosystems, 3, 193-209. https://doi.org/10.1007/s100210000019

[39] Bigelow, S.W. and Canham, D.C. (2010) Evidence That Soil Aluminium Enforces Site Fidelity of Southern New England Forest Trees. Rhodora, 112, 1-21. https://doi.org/10.3119/08-32.1

[40] Raynal, D.J., Joslin, J.D., Thornton, F.C., Schaedle, M. and Henderson, G.S. (1990) Sensitivity of Tree Seedlings to Aluminum: III. Red Spruce and Loblolly Pine. Journal of Environmental Quality, 19, 180-187. https://doi.org/10.2134/jeq1990.00472425001900020003x

[41] Meriga, B., Attitalla, I.H., Ramgopal, M., Ediga, A. and Kavikishir, P.B. (2010) Differential Tolerance of Aluminium Toxicity in Rice Cultivars: Involvement of Antioxidative Enzymes and Possible Role of Aluminium Resistant Locus. Academy Journal of Plant Science, 3, 53-63.

[42] Amani, A.C. and Lejoly, J. (2014) Floristic Patterns and Impact of Edaphic Heterogeneity on Species Assemblages within Woody Forests Layers in Semi-Deciduous Forests from the Congo Basin. Greener Journal of Agronomy, Forestry and Horticulture, 2, 62-72. https://doi.org/10.15580/GJAFH.2014.3.

[43] Reed, S.C., Cleveland, C.C. and Townsend, A.R. (2008) Tree Species Control Rates of Free-Living Nitrogen Fixation in a Tropical Rain Forest. Ecology, 89, 2924-2934. https://doi.org/10.1890/07-1430.1

[44] Palove-Balang, P. and Mistrík, I. (2007) Impact of Low pH and Aluminium on Nitrogen Uptake and Metabolism in Roots of Lotus japonicas. Biologia, 62, 715-719.

[45] Gupta, P., Sarengthem, J., Dhamgaye, S. and Gadre, R. (2016) Differential Effect of 
Aluminium on Enzymes of Nitrogen Assimilation in Excised Bean Leaf Segments. Advances in Biological Chemistry, 6, 106-113.

https://doi.org/10.4236/abc.2016.63009

[46] Pilbeam, D.J. and Morley, P.S. (2007) Calcium. In: Barker, V.A. and Pilbeam, J.D., Eds., Handbook of Plant Nutrition, CRC Press, Taylor and Francis Group, Boca Raton, 121-144.

[47] Zinn, Y.L., Lal, R. and Resck, D.V.S. (2005) Texture and Organic Carbon Relations Described by a Profile Pedotransfer Function for Brazilian Cerrado Soils. Geoderma, 127, 168-173. https://doi.org/10.1016/j.geoderma.2005.02.010

[48] Grigal, D.F. and Vance, E.D. (2000) Influence of Soil Organic Matter on Forest Productivity. New Zealand Journal of Forestry Science, 30, 169-205.

[49] Newbery, D.M., Van Der Burgt, X.M., Worbes, M. and Chuyong, G.B. (2013) Transient Dominance in a Central African Rain Forest. Ecological Monographs, 83, 339-382. https://doi.org/10.1890/12-1699.1

[50] Pélissier, R., Dray, S. and Sabatier, D. (2001) Within-Plot Relationships between Tree Species Occurrences and Hydrological Soil Constraints: An Example in French Guiana Investigated through Canonical Correlation Analysis. Plant Ecology, 162, 143-156. https://doi.org/10.1023/A:1020399603500

[51] Doucet, J.L., Daïnou, K., Ligot, G., Ouédraogo, D.K., Bourland, N., Ward, S.E., Tekam, P., Lagoute, P. and Fayolle, A. (2016) Enrichment of Central African Logged Forests with High-Value Tree Species: Testing a New Approach to Regenerating Degraded Forests. International Journal of Biodiversity Science, Ecosystem Services and Management, 12, 83-95.

https://doi.org/10.1080/21513732.2016.1168868 